\title{
PENGARUH FREKUENSI PEMBERIAN CATATAN PERBAIKAN PADA LATIHAN MATEMATIKA TERHADAP KEMAMPUAN PEMAHAMAN MATEMATIKA
}

\author{
Ade Lukman Nulhakim \\ Program Studi Teknik Informatika, Universitas Indraprasta PGRI \\ Email: vlh1330@gmail.com
}

\begin{abstract}
Abstrak
Tujuan dari penelitian ini adalah untuk mengetahui pengaruh pemberian catatan perbaikan yang diberikan dengan frekuensi selalu, jarang, dan tidak diberikan terhadap kemampuan pemahaman matematika siswa. Metode penelitian adalah kuasi eksperimen dengan kelompok eksperimen 1 selalu diberi catatan perbaikan, kelompok eksperimen 2 jarang diberi catatan perbaikan, dan kelompok eksperimen 3 tidak diberi catatan perbaikan. Penelitian ini dilakukan di SMP Negeri 2 Balaraja dengan populasi penelitian siswa SMP kelas VIII. Sedangkan banyak sampel sebanyak 3 kelas yang diambil dari 9 kelas VIII secara random sebanyak 136 siswa. Dari penelitian ditemukan bahwa: 1) Terdapat perbedaan kemampuan pemahaman matematika siswa antara siswa yang selalu diberi catatan perbaikan dengan yang jarang diberi catatan perbaikan. $t_{\text {hitung }}>t_{\text {tabel }(89,0,05)}$, yaitu 4,227 >1,990.2) Terdapat perbedaan kemampuan pemahaman matematika siswa antara siswa yang selalu diberi catatan perbaikan dengan yang tidak diberi catatan perbaikan. $t_{\text {hitung }}>t_{\text {tabel }}(89,0,05)$, yaitu $8,772>1,990$. 3) Terdapat perbedaan kemampuan pemahaman matematika siswa antara siswa yang jarang diberi catatan perbaikan dengan yang tidak diberi catatan perbaikan. $\mathrm{t}_{\text {hitung }}$ $>t_{\text {tabel }}(88,0,05)$, yaitu $4,30>1,990$.
\end{abstract}

Kata kunci: pemberian catatan perbaikan, latihan matematika, pemahaman matematika.

\section{Pendahuluan}

Pendidikan merupakan bagian yang penting dalam kehidupan manusia. Salah satu bagian yang berkaitan dengan pendidikan adalah proses pembelajaran. Pendidikan dan pembelajaran merupakan sesuatu aktivitas yang terjadi melalui interaksi antara siswa yang belajar dengan guru yang mengajar. Perkembangan potensi siswa di sekolah dikembangkan melalui pendampingan guru dalam proses pembelajaran yang salah satunya melalui penyampaian materi mata pelajaran matematika. Potensi siswa yang dapat dikembangkan dalam pembelajaran matematika adalah agar muncul keterampilan berhitung dan menyelesaikan masalah matematika dari diri siswa. Matematika sebagai salah satu mata pelajaran yang diajarkan di sekolah ternyata sampai saat ini belum menjadi mata pelajaran favorite, bahkan oleh sebagian besar siswa masih dianggap sebagai pelajaran yang sukar. Siswa menganggap belajar matematika adalah belajar mengingat rumus-rumus tetapi kurang berusaha memahami isi materinya.

Pemahaman dalam pembelajaran matematika sangat penting karena pemahaman merupakan pondasi dasar untuk menguasai matematika. Hal ini mengingat matematika adalah ilmu yang terstruktur dalam arti antara bagian yang satu dengan bagian yang lainnya terjalin dalam hubungan fungsional yang erat dan saling berkaitan, dan untuk mempelajari topik-topik dalam matematika terdapat topik atau konsep prasyarat sebagai dasar untuk memahami topik atau konsep selanjutnya. Hal ini juga sejalan dengan pernyataan (TIM MKPBM, 2003) yang menyatakan bahwa matematika sebagai ilmu yang terstruktur yaitu materi satu berkaitan dengan materi selanjutnya, jika pemahaman konsep matematika yang sekarang rendah, maka kemungkinan besar pada tingkat selanjutnya akan rendah.

Kemampuan siswa dalam satu kelas berdasarkan keterampilan menyelesaikan persoalan matematika terdiri atas siswa berkemampuan tinggi, sedang dan rendah. Siswa 
berkemampuan tinggi cenderung bisa menyelesaikan latihan-latihan soal matematika dengan baik. Namun, siswa yang berkemampuan sedang dan rendah masih cenderung sering mengalami berbagai kesulitan-kesulitan dalam menyelesaikan soal-soal matematika. Kesulitan siswa menyelesaikan soal matematika ini dapat disebabkan karena mereka kurang memiliki kemampuan pemahaman matematika, dan saat mendapatkan hasil tes yang kurang baik siswa tersebut cenderung tidak memanfaatkan kesempatan untuk konsultasi atau bertanya kepada guru mengenai kekeliruan, kesalahan atau kekurang tepatan yang dilakukannya. Biasanya ini terjadi karena siswa takut dan malu untuk bertanya pada guru matematika tersebut. Perlu upaya lain untuk mengantisipasi permasalahan tersebut, salah satunya dengan pemberian catatan-catatan pada setiap kesalahan yang dilakukan siswa untuk mereka lihat dan pahami dan kemudian mereka perbaiki ulang.

Pemberian catatan perbaikan dapat diberikan dengan frekuensi selalu, jarang dan tidak. Pemberian catatan perbaikan pada setiap latihan soal matematika merupakan salah satu solusi untuk membantu kesulitan belajar siswa. Namun, kebanyakan guru setelah menilai jawaban siswa biasanya tidak memberikan penjelasan mengenai jawaban yang seharusnya siswa kerjakan dan membiarkan siswa mencari tahu jawaban yang benar dengan kemampuannya sendiri. Selama ini guru biasa hanya melihat dari sudut pandang bahwa jawaban siswa tersebut benar atau salah dengan mengabaikan langkah-langkah dan proses pembentukan jawaban yang dilakukan siswa. Menurut (Wilis, 1996) hukum pembentukan (shaping) ialah proses penguraian suatu tugas menjadi beberapa langkah, dan memberikan umpan balik pada setiap langkah yang telah dilakukan. Dari ungkapan tersebut maka perlu umpan balik terhadap jawaban siswa yang masih dianggap salah dalam penelitian ini diberikan dalam bentuk catatan-catatan.

Siswa selalu membutuhkan suatu kepastian dari kegiatan latihan yang dilakukan, apakah benar atau salah. Dengan demikian diharapkan siswa akan selalu memiliki pengetahuan tentang hasil (knowledge of result), yang sekaligus penguat (reinforce) bagi dirinya sendiri. Seorang siswa belajar lebih banyak bilamana setiap langkah segera diberikan penguatan (reinforcement) (Davies dalam Dimyati dan Mudjiono, 2006). Hal ini timbul karena kesadaran adanya kebutuhan untuk memperoleh balikan dan sekaligus penguat bagi setiap kegiatan yang dilakukannya. Untuk memperoleh balikan penguatan bentuk-bentuk perilaku siswa yang memungkinkan di antaranya dengan segera mencocokkan jawaban dengan kunci jawaban, menerima kenyataan terhadap skor atau nilai yang dicapai, atau menerima teguran dari guru atau orang tua karena hasil belajar yang jelek. Menurut Shimada (dalam TIM MKPBM, 2003) dalam pembelajaran matematika, rangkaian dari pengetahuan, keterampilan konsep, prinsip atau aturan diberikan kepada siswa biasanya melalui langkah demi langkah. Tentu saja rangkaian ini diajarkan tidak sebagai hal yang saling terpisah atau saling lepas, namun harus disadari sebagai rangkaian yang terintegrasi dengan kemampuan dan sikap dari setiap siswa, sehingga di dalam pemikirannya terjadi pengorganisasian intelektual yang optimal.

Penelitian ini bertujuan untuk mengetahui pengaruh pemberian catatan perbaikan antara siswa yang selalu, jarang dan tidak diberi catatan perbaikan terhadap kemampuan pemahaman matematika siswa berkemampuan tinggi, sedang dan rendah. Hasil penelitian ini diharapkan bisa bermanfaat bagi semua pihak, di antaranya: 1) sebagai bahan pertimbangan dan informasi bagi guru SMP khususnya guru matematika mengenai pengaruh pemberian catatan perbaikan pada latihan dan tugas-tugas siswa terhadap kemampuan pemahaman matematika; 2) catatan perbaikan pada setiap latihan matematika dapat membantu meningkatkan kemampuan pemahaman siswa dalam memahami matematika; serta 3) sebagai masukan untuk meningkatkan mutu pendidikan.

\section{Tinjauan Pustaka}




\section{Kemampuan Pemahaman Matematika}

Kemampuan menurut Gordon (Mulyasa, 2004) adalah sesuatu yang dimiliki oleh individu untuk melakukan tugas atau pekerjaan yang dibebankan kepadanya. Menurut (Munandar, 1992) kemampuan merupakan daya untuk melakukan sesuatu tindakan sebagai hasil dari pembawaan dan latihan. Menurut (Gunawan, 2001) kemampuan berarti kesanggupan; kecakapan; kekuatan. Sedangkan (Munandar, 1987) memberikan batasan bahwa kemampuan atau kesanggupan merupakan kecakapan atau kekuatan seseorang untuk dapat berbuat atau melakukan suatu tindakan sebagai hasil dari pembawaan dan latihan. Pada dasarnya suatu kemampuan sudah ada pada diri seseorang. Seseorang yang kemampuannya lebih tinggi dalam bidang matematika diperkirakan akan mencapai prestasi dalam bidang itu. Keberhasilan dalam penyesuaian dari seseorang tergantung kemampuan berpikir dan belajar. Dapat disimpulkan bahwa kemampuan merupakan kesanggupan, kecakapan atau kekuatan yang dimiliki oleh seseorang baik itu dari pembawaan maupun sejak lahir yang dapat diwujudkan setelah melalui latihan dan proses belajar. Dan sudah menjadi kenyataan bahwa dalam proses belajar mengajar terdapat tujuan tertentu atau dengan perkataan lain, dalam setiap kegiatan belajar mengajar diharapkan adanya perubahan tersebut yang meliputi tiga aspek, yaitu kategori kognitif, afektif dan psikomotor.

Menurut Bloom (Hilaliyah, 2004) dalam kategori kognitif dalam sebuah pembelajaran matematika terdapat enam peningkatan mengenai taraf tujuan yaitu pengetahuan/mengenal (recognition), pemahaman (comprehension), penerapan/aplikasi (application), analisis (analysis), sintesis (synthesis), dan evaluasi (evaluation). Pemahaman menurut Gordon (Mulyasa, 2004) yaitu kedalaman kognitif dan afektif yang dimiliki individu. Pemahaman memerlukan pemikiran dan karena itu lebih sulit dari pada pengetahuan (yang memerlukan daya ingatan). Pemahaman dapat merupakan kesanggupan menyatakan suatu definisi, rumusan, kata yang sulit dengan perhatian sendiri. Dapat pula merupakan kemampuan untuk menafsirkan suatu teori, atau melihat konsekuensi atau implikasi, meramalkan kemungkinan atau akibat sesuatu. Dengan memahami proses pembentukan (shapping) suatu konsep matematik secara tidak langsung akan memberikan kemudahan kepada diri siswa untuk lebih memahami, mengerti dan mempermudah penerapan konsep matematika. Menurut Ausubel (Wilis, 1996) belajar bermakna merupakan suatu proses mengaitkan informasi baru pada konsep-konsep relevan yang terdapat dalam struktur kognitif seseorang.

Pemahaman diartikan sebagai suatu kemampuan yang harus diutamakan oleh siswa dalam terbentuknya suatu konsep dan menguasai suatu materi. Tanpa adanya pemahaman siswa tidak akan menguasai konsep tersebut, dan pada akhirnya siswa tidak akan mampu menerapkan konsep tersebut. Jadi disimpulkan bahwa kemampuan pemahaman matematika merupakan suatu kesanggupan untuk menyatakan suatu definisi, rumusan, kata yang sulit dengan perhatian sendiri dan dengan kecakapan yang dimiliki individu untuk menyelesaikan tugas dan sebagai tindakan hasil dari pembawaan dan latihan matematika.

\section{Belajar dan Latihan}

Menurut Thorndike (Dimyati dan Mudjiono, 2006) dalam hukum law of exercise, mengemukakan bahwa belajar ialah pembentukan hubungan antara stimulus dan respon, dan pengulangan terhadap pengalaman-pengalaman itu memperbesar peluang timbulnya respons benar. Penguasaan secara penuh dari setiap langkah memungkinkan belajar secara keseluruhan lebih berarti (Davies dalam Dimyati dan Mudjiono, 2006). Dari penyataan inilah pengulangan masih diperlukan dalam kegiatan pembelajaran. Implikasi adanya prinsip pengulangan bagi siswa adalah kesadaran siswa untuk bersedia mengerjakan latihan-latihan yang berulang untuk satu macam permasalahan. Dengan kesadaran ini, diharapkan siswa tidak akan merasa bosan dalam melakukan pengulangan. Belajar dikatakan sebagai proses di mana tingkah laku ditimbulkan atau diubah melalui latihan atau pengalaman (Whitaks, 1970). Menurut Hilgard (Nasution, 1986) belajar adalah sebagai proses yang melahirkan 
atau mengubah sesuatu melalui jalan latihan. Sedangkan Howord L Kingsley (Bahri, 2002) belajar adalah proses di mana tingkah laku (dalam arti luas) ditimbulkan atau diubah melalui praktik atau latihan.Dapat disimpulkan bahwa belajar merupakan suatu perubahan yang relatif menetap yang terjadi melalui latihan dan pengalaman serta terjadi apabila suatu situasi stimulus bersama dengan isi ingatan memengaruhi siswa sedemikian rupa sehingga perbuatannya berubah dari waktu sebelum ia mengalami situasi itu ke waktu sesudah ia mengalami situasi tadi, perubahan itu meliputi kecakapan, sikap, kebiasaan, kepandaian.

Menurut Bahri (2002) metode latihan disebut juga metode training, yaitu suatu cara mengajar untuk menanamkan kebiasaan tertentu, juga sebagai sarana untuk memelihara kebiasaan yang baik. Selain itu, metode ini dapat digunakan untuk memperoleh suatu ketangkasan, ketepatan, kesepahaman dan keterampilan. Metode latihan secara tertulis dapat diberikan di kelas dan sebagai tugas pekerjaan rumah. Setiap latihan dapat memengaruhi kemampuan seseorang dalam segi pemahaman dan kematangan berpikirnya. Dapat disimpulkan bahwa latihan merupakan suatu cara dalam pembelajaran matematika agar siswa lebih terampil melakukan pekerjaan secara cepat dan tepat.

\section{Catatan Perbaikan}

Menurut (Gunawan, 2001) catatan adalah tulisan untuk diingat agar tidak lupa. Sedangkan menurut (Tim Penyusun Kamus Pusat Bahasa, 2005) catatan berarti menuliskan sesuatu untuk peringatan. Jadi dapat disimpulkan bahwa catatan merupakan tulisan yang diberikan seorang (guru) kepada seorang (siswa) berupa peringatan tentang kesalahannya agar ia tidak lupa. Menurut (Gunawan, 2001) perbaikan yaitu pembetulan; hal (hasil, perbuatan, usaha dan sebagainya). Dapat disimpulkan perbaikan berarti mengubah sesuatu yang kurang baik menjadi baik. Jadi catatan perbaikan merupakan tulisan peringatan yang diberikan oleh seorang guru kepada siswa karena siswa tersebut dalam keadaan membutuhkan pertolongan yaitu pembimbingan kepada arah perbaikan agar perbuatannya menjadi lebih baik.

Pengajaran perbaikan menurut (Bahri, 2002) mengandung kegiatan sebagai berikut: 1) mengulang pokok bahasan sebelumnya, 2) mengulang sebagian dari pokok bahasan yang hendak dikuasai, 3)memecahkan masalah atau menyelesaikan soal-soal bersama-sama, dan 4) memberikan tugas-tugas khusus. Tujuan catatan perbaikan adalah memberikan penjelasan pada langkah-langkah mendapatkan hasil atau jawaban dari setiap latihan. Hal ini penting agar pengetahuan dan pemahaman siswa yang mereka miliki dapat mereka pahami sendiri, apakah jawaban yang mereka kerjakan benar atau salah.

\section{Metodologi Penelitian}

Secara umum penelitian ini bertujuan untuk mengetahui apakah terdapat pengaruh pemberian catatan perbaikan terhadap kemampuan pemahaman matematika siswa. Penelitian ini dilaksanakan di SMP Negeri 2 Balaraja pada siswa kelas VIII tahun pelajaran 2008 dengan jumlah sampel sebanyak 136 siswa. Desain penelitian yang digunakan dalam penelitian ini menggunakan metode kuasi eksperimen dengan tiga kelompok yang diberi perlakuan berbeda.

\section{Hasil dan Pembahasan}

\section{Hasil Penelitian}

Hasil perhitungan tes kemampuan pemahaman matematika kelompok eksperimen 1, 2, dan 3 antara kemampuan tinggi, sedang dan rendah adalah sebagai berikut:

1. Perhitungan yang telah dilakukan berdasarkan frekuensi pemberian catatan perbaikan (kolom), diperoleh harga $F_{\text {hitung }}($ kolom $)=51,375$ ternyata lebih besar dari $F_{\text {tabel }}=3,07$. Dengan demikian maka $\mathrm{H}_{0}$ ditolak dan $\mathrm{H}_{\mathrm{a}}$ diterima. Hal ini berarti terdapat perbedaan 
kemampuan pemahaman matematika siswa antara siswa yang selalu, jarang dan tidak diberi catatan perbaikan.

2. Perhitungan yang telah dilakukan berdasarkan tingkat inteligensi (baris). diperoleh harga Harga $F_{\text {hitung }}$ (baris) $=26,122$ ternyata lebih besar dari $F_{\text {tabel }}=3,07$. Dengan demikian $\mathrm{H}_{0}$ ditolak. Hal ini berarti terdapat perbedaan kemampuan pemahaman matematika antara siswa berkemampuan tinggi, sedang dan rendah.

3. Untuk interaksi. Harga $F_{\text {hitung }}=1,161$ ternyata lebih kecil daripada $F_{\text {tabel }(4,127)}$ yaitu 2,44 . Dengan demikian $\mathrm{H}_{\mathrm{a}}$ ditolak, dengan kata lain, tidak terdapat interaksi yang signifikan antara siswa yang selalu, jarang, dan tidak diberi catatan perbaikan dengan kemampuan pemahaman matematika siswa berkemampuan tinggi, sedang dan rendah.

Untuk mengetahui kelompok eksperimen yang memiliki beda signifikan di antara ketiga kelompok eksperimen, maka digunakan uji ANOVA dua-jalur menggunakan uji- $F$. Sedangkan rumus untuk membandingkan dua rata-rata menggunakan uji- $t$ menurut (Sugiyono, 2007). Hasil perhitungan uji-t ialah sebagai berikut:

1. Pengujian Hipotesis 1: Terdapat Perbedaan Kemampuan Pemahaman Matematika antara Kelompok $\mathrm{X}_{1}$ Berkemampuan Tinggi (Selalu) dengan Berkemampuan Tinggi $\mathrm{X}_{2}$ (Jarang).

Dari perhitungan diperoleh $t_{\text {hitung }}>t_{\text {tabel }}(32,0,05)$, yaitu 3,511 $>2,032$. Ini berarti $H_{0}$ di di tolak, sehingga terdapat perbedaan kemampuan pemahaman matematika yang signifikan pada kelompok eksperimen 1 berkemampuan tinggi yang selalu diberi catatan perbaikan terhadap kelompok eksperimen 2 berkemampuan tinggi yang jarang diberi catatan perbaikan.

2. Pengujian Hipotesis 2; Terdapat Perbedaan Kemampuan Pemahaman Matematika antara Kelompok $\mathrm{X}_{1}$ Berkemampuan Tinggi (Selalu) dengan Berkemampuan Tinggi $\mathrm{X}_{3}$ (Tidak).

Dari perhitungan diperoleh $t_{\text {hitung }}>t_{\text {tabel }}(33,0,05)$, yaitu 8,641 $>2,032$. Ini berarti $H_{0}$ di tolak, sehingga terdapat perbedaan kemampuan pemahaman matematika yang signifikan pada kelompok eksperimen 1 berkemampuan tinggi yang selalu diberi catatan perbaikan terhadap kelompok eksperimen 3 berkemampuan tinggi yang tidak diberi catatan perbaikan.

3. Pengujian Hipotesis 3; Terdapat Perbedaan Kemampuan Pemahaman Matematika antara Kelompok $\mathrm{X}_{2}$ Berkemampuan Tinggi (Jarang) dengan Berkemampuan Tinggi $\mathrm{X}_{3}$ (Tidak) .

Dari perhitungan diperoleh $t_{\text {hitung }}>t_{\text {tabel }(33,0,05)}$, yaitu 3,999 > 2,032. Ini berarti $H_{0}$ di tolak, sehingga terdapat perbedaan kemampuan pemahaman matematika yang signifikan pada kelompok eksperimen 2 berkemampuan tinggi yang jarang diberi catatan perbaikan terhadap kelompok eksperimen 3 berkemampuan tinggi yang tidak diberi catatan perbaikan.

4. Pengujian Hipotesis 4; Terdapat Perbedaan Kemampuan Pemahaman Matematika antara Kelompok $\mathrm{X}_{4}$ Berkemampuan Sedang (Selalu) dengan Berkemampuan Sedang $\mathrm{X}_{5}$ (Jarang).

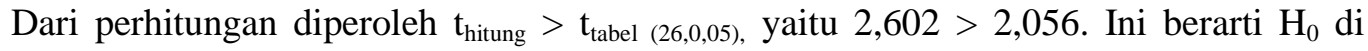
tolak, sehingga terdapat perbedaan kemampuan pemahaman matematika yang signifikan pada kelompok eksperimen 1 berkemampuan sedang yang selalu diberi catatan perbaikan terhadap kelompok eksperimen 2 berkemampuan sedang yang jarang diberi catatan perbaikan.

5. Pengujian Hipotesis 5; Terdapat Perbedaan Kemampuan Pemahaman Matematika antara Kelompok $\mathrm{X}_{4}$ Berkemampuan Sedang (Selalu) dengan Berkemampuan Sedang $\mathrm{X}_{6}$ (Tidak).

Dari perhitungan diperoleh $t_{\text {hitung }}>t_{\text {tabel }(18,0,05)}$, yaitu 5,676 $>2,140$. Ini berarti $\mathrm{H}_{0}$ di tolak, sehingga terdapat perbedaan kemampuan pemahaman matematika yang signifikan pada kelompok eksperimen 1 berkemampuan sedang yang selalu diberi 
catatan perbaikan terhadap kelompok eksperimen 3 berkemampuan sedang yang tidak diberi catatan perbaikan.

6. Pengujian Hipotesis 6; Terdapat Perbedaan Kemampuan Pemahaman Matematika antara Kelompok $\mathrm{X}_{5}$ Berkemampuan Sedang (Jarang) dengan Berkemampuan Sedang $\mathrm{X}_{6}$ (Tidak).

Dari perhitungan diperoleh $t_{\text {hitung }}>t_{\text {tabel }(18,0,05)}$, yaitu $3,815>2,123$. Ini berarti $\mathrm{H}_{0}$ di tolak, sehingga terdapat perbedaan kemampuan pemahaman matematika yang signifikan pada kelompok eksperimen 2 berkemampuan sedang yang jarang diberi catatan perbaikan terhadap kelompok eksperimen 3 berkemampuan sedang yang tidak diberi catatan perbaikan.

7. Pengujian Hipotesis 7; Terdapat Perbedaan Kemampuan Pemahaman Matematika antara Kelompok $\mathrm{X}_{7}$ Berkemampuan Rendah (Selalu) dengan Berkemampuan Rendah $\mathrm{X}_{8}$ (Jarang).

Dari perhitungan diperoleh $\mathrm{t}_{\text {hitung }}<\mathrm{t}_{\text {tabel }(27,0,05)}$, yaitu $1,959<2,052$. Ini berarti $\mathrm{H}_{0}$ di terima, sehingga tidak terdapat perbedaan kemampuan pemahaman matematika yang signifikan pada kelompok eksperimen 1 berkemampuan rendah yang selalu diberi catatan perbaikan terhadap kelompok eksperimen 2 berkemampuan rendah yang jarang diberi catatan perbaikan.

8. Pengujian Hipotesis 8; Terdapat Perbedaan Kemampuan Pemahaman Matematika antara Kelompok $\mathrm{X}_{7}$ Berkemampuan Rendah (Selalu) dengan Berkemampuan Rendah $\mathrm{X}_{9}$ (Tidak).

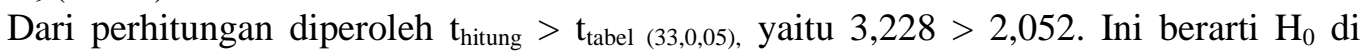
tolak, sehingga terdapat perbedaan kemampuan pemahaman matematika yang signifikan pada kelompok eksperimen 1 berkemampuan rendah yang selalu diberi catatan perbaikan terhadap kelompok eksperimen 3 berkemampuan rendah yang tidak diberi catatan perbaikan.

9. Pengujian Hipotesis 9; Terdapat Perbedaan Kemampuan Pemahaman Matematika antara Kelompok $\mathrm{X}_{8}$ Berkemampuan Rendah (Jarang) dengan Berkemampuan Rendah $\mathrm{X}_{9}$ (Tidak).

Dari perhitungan diperoleh $t_{\text {hitung }}>t_{\text {tabel }}(25,0,05)$, yaitu $1,280<2,060$. Ini berarti $\mathrm{H}_{0}$ di tolak, sehingga tidak terdapat perbedaan kemampuan pemahaman matematika yang signifikan pada kelompok eksperimen 2 berkemampuan rendah yang jarang diberi catatan perbaikan terhadap kelompok eksperimen 3 berkemampuan rendah yang tidak diberi catatan perbaikan.

10. Pengujian Hipotesis 10; Terdapat Perbedaan Kemampuan Pemahaman Matematika antara Kelompok $\mathrm{X}_{1}$ Berkemampuan Tinggi (Selalu) dengan Berkemampuan Sedang $\mathrm{X}_{4}$ (Selalu).

Dari perhitungan diperoleh $t_{\text {hitung }}>t_{\text {tabel }(31,0,05)}$, yaitu 3,326 $>2,042$. Ini berarti $H_{0}$ di tolak, sehingga terdapat perbedaan kemampuan pemahaman matematika yang signifikan pada kelompok eksperimen 1 berkemampuan tinggi yang selalu diberi catatan perbaikan terhadap kelompok eksperimen 1 berkemampuan sedang yang selalu diberi catatan perbaikan.

11. Pengujian Hipotesis 11; Terdapat Perbedaan Kemampuan Pemahaman Matematika antara Kelompok $\mathrm{X}_{1}$ Berkemampuan Tinggi (Selalu) dengan Berkemampuan Rendah $\mathrm{X}_{7}$ (Selalu).

Dari perhitungan diperoleh $t_{\text {hitung }}>t_{\text {tabel }(31,0,05)}$, yaitu 5,642 $>2,042$. Ini berarti $\mathrm{H}_{0}$ di tolak, sehingga terdapat perbedaan kemampuan pemahaman matematika yang signifikan pada kelompok eksperimen 1 berkemampuan tinggi yang selalu diberi catatan perbaikan terhadap kelompok eksperimen 1 berkemampuan rendah yang selalu diberi catatan perbaikan.

12. Pengujian Hipotesis 12 Terdapat Perbedaan Kemampuan Pemahaman Matematika antara Kelompok $\mathrm{X}_{4}$ Berkemampuan Sedang (Selalu) dengan Berkemampuan Rendah $\mathrm{X}_{7}$ (Selalu). 
Dari perhitungan diperoleh $t_{\text {hitung }}>t_{\text {tabel }(12,0,05)}$, yaitu $2,707>2,179$. Ini berarti $\mathrm{H}_{0}$ di tolak, dengan perkataan lain, terdapat perbedaan kemampuan pemahaman matematika yang signifikan pada kelompok eksperimen 1 berkemampuan sedang yang selalu diberi catatan perbaikan terhadap kelompok eksperimen 1 berkemampuan rendah yang selalu diberi catatan perbaikan.

13. Pengujian Hipotesis 13; Terdapat Perbedaan Kemampuan Pemahaman Matematika antara Kelompok $\mathrm{X}_{1}$ Berkemampuan Tinggi (Jarang) dengan Berkemampuan Sedang $\mathrm{X}_{4}$ (Jarang).

Dari perhitungan diperoleh $\mathrm{t}_{\text {hitung }}=1,423$ lebih kecil dari $\mathrm{t}_{\text {tabel }}=2,052$. Ini berarti $\mathrm{H}_{0} \mathrm{di}$ tolak, sehingga tidak terdapat perbedaan kemampuan pemahaman matematika yang signifikan pada kelompok eksperimen 2 berkemampuan tinggi yang jarang diberi catatan perbaikan terhadap kelompok eksperimen 2 berkemampuan sedang yang jarang diberi catatan perbaikan.

14. Pengujian Hipotesis 14; Terdapat Perbedaan Kemampuan Pemahaman Matematika antara Kelompok $\mathrm{X}_{2}$ Berkemampuan Tinggi (Jarang) dengan Berkemampuan Rendah $\mathrm{X}_{8}$ (Jarang).

Dari perhitungan diperoleh $t_{\text {hitung }}=4,154$ lebih besar dari $t_{\text {tabel }}=2,048$. Ini berarti $\mathrm{H}_{0}$ di tolak, sehingga terdapat perbedaan kemampuan pemahaman matematika yang signifikan pada kelompok eksperimen 2 berkemampuan tinggi yang jarang diberi catatan perbaikan terhadap kelompok eksperimen 2 berkemampuan rendah yang jarang diberi catatan perbaikan.

15. Pengujian Hipotesis 15; Terdapat Perbedaan Kemampuan Pemahaman Matematika antara Kelompok $\mathrm{X}_{5}$ Berkemampuan Sedang (Jarang) dengan Berkemampuan Rendah $\mathrm{X}_{8}$ (Jarang).

Dari perhitungan diperoleh $t_{\text {hitung }}=3,629$ lebih besar dari $t_{\text {tabel }}=2,138$. Ini berarti $\mathrm{H}_{0}$ di tolak, sehingga terdapat perbedaan kemampuan pemahaman matematika yang signifikan pada kelompok eksperimen 2 berkemampuan sedang yang jarang diberi catatan perbaikan terhadap kelompok eksperimen 2 berkemampuan rendah yang jarang diberi catatan perbaikan.

16. Pengujian Hipotesis 16; Terdapat Perbedaan Kemampuan Pemahaman Matematika antara Kelompok $\mathrm{X}_{3}$ Berkemampuan Tinggi (Tidak) dengan Berkemampuan Sedang $\mathrm{X}_{6}$ (Tidak).

Dari perhitungan diperoleh $\mathrm{t}_{\text {hitung }}=0,384$ lebih kecil dari $\mathrm{t}_{\text {tabel }}=2,042$. Ini berarti $\mathrm{H}_{0}$ diterima, sehingga tidak terdapat perbedaan kemampuan pemahaman matematika yang signifikan pada kelompok eksperimen 3 berkemampuan tinggi yang tidak diberi catatan perbaikan terhadap kelompok eksperimen 3 berkemampuan sedang yang tidak diberi catatan perbaikan.

17. Pengujian Hipotesis 17; Terdapat Perbedaan Kemampuan Pemahaman Matematika antara Kelompok $\mathrm{X}_{3}$ Berkemampuan Tinggi (Tidak) dengan Berkemampuan Rendah $\mathrm{X}_{9}$ (Tidak).

Dari perhitungan diperoleh $\mathrm{t}_{\text {hitung }}=2,348$ lebih kecil dari $\mathrm{t}_{\text {tabel }}$. Ini berarti $\mathrm{H}_{0}$ ditolak, sehingga tidak terdapat perbedaan kemampuan pemahaman matematika yang signifikan pada kelompok eksperimen 3 berkemampuan tinggi yang tidak diberi catatan perbaikan terhadap kelompok eksperimen 3 berkemampuan rendah yang tidak diberi catatan perbaikan.

18. Pengujian Hipotesis 18; Terdapat Perbedaan Kemampuan Pemahaman Matematika antara Kelompok $\mathrm{X}_{6}$ Berkemampuan Sedang (Tidak) dengan Berkemampuan Rendah $\mathrm{X}_{9}$ (Tidak).

Dari perhitungan diperoleh $t_{\text {hitung }}=1,135$ lebih kecil dari $\mathrm{t}_{\text {tabel }}=2,048$. Ini berarti $\mathrm{H}_{0}$ diterima, sehingga tidak terdapat perbedaan kemampuan pemahaman matematika yang signifikan pada kelompok eksperimen 3 berkemampuan sedang yang tidak diberi catatan perbaikan terhadap kelompok eksperimen 3 berkemampuan rendah yang tidak diberi catatan perbaikan. 


\section{Pembahasan}

Berdasarkan uji hipotesis dengan uji- $t$ dapat disimpulkan bahwa pemberian catatan perbaikan selalu berpengaruh positif terhadap kemampuan pemahaman matematika siswa daripada pemberian catatan perbaikan jarang dan tidak. Siswa yang selalu diberitahukan kesalahannya ternyata memiliki potensi yang jauh lebih berkembang dan akan cenderung memiliki kemampuan yang lebih baik daripada siswa yang jarang diberitahukan kesalahannya, dan atau dibiarkan saja tanpa diberitahukan kesalahannya. Sejalan dengan teori Thorndike (2001) bahwa jika kekeliruan anak dibiarkan tanpa penjelasan yang benar dari guru, ada kemungkinan anak akan mengulang kesalahan yang sama. Kemungkinan anak akan menganggap jawabannya benar dan melakukan kesalahan yang berulang, jika anak melakukan kesalahan yang berulang maka akan berakibat pada hasil belajar menjadi rendah. Berdasarkan kesimpulan tersebut, siswa berkemampuan tinggi cenderung memiliki kemampuan yang jauh lebih baik dibandingkan dengan kemampuan sedang dan rendah jika siswa tersebut dibimbing dan selalu diarahkan.

Kegiatan belajar merupakan kegiatan yang paling pokok dalam keseluruhan proses pendidikan di sekolah. Karena itu berhasil atau tidaknya pencapaian tujuan pendidikan bergantung kepada bagaimana proses belajar yang dialami siswa dalam proses pendidikan tersebut. Matematika sering kali dianggap pelajaran sulit oleh siswa, karena dalam mempelajari dibutuhkan pemahaman konsep-konsep yang terdapat di dalam matematika. Salah satu materi yang membutuhkan pemahaman konsep adalah pada materi fungsi, karena pada pokok bahasan ini banyak terdapat aturan atau konsep matematika yang perlu pahami oleh siswa, sehingga dalam mempelajari materi tersebut dibutuhkan kemampuan yang sesuai serta harus memperbanyak latihan-latihan menyelesaikan soal-soal. Berkaitan hal tersebut terdapat masalah dalam pendidikan matematika di sekolah, yaitu bagaimana menjadikan pengalaman yang dialami siswa saat menyelesaikan latihan, dapat memberikan pemahaman kepada mereka sehingga siswa dalam menyelesaikan latihannya dapat mengoptimalkan potensi dirinya, dan hasilnya pada saat diadakan latihan kembali, siswa tidak mengulangmengulang kesalahan yang sama.

Berdasarkan permasalahan di atas, maka perlu diberikan suatu model pembelajaran untuk mengatasinya tersebut dan menjadi penguat tentang kegiatan yang dilakukan siswa sehingga dapat meningkatkan kemampuan pemahaman matematika. Salah satu model pembelajaran yang dapat diterapkan untuk mengatasi rendahnya kemampuan pemahaman matematika adalah dengan pemberian catatan perbaikan.

Pemberian catatan perbaikan merupakan model pembelajaran dengan cara memberikan informasi kepada siswa mengenai tugas atau latihan siswa yang tidak tepat, hal ini agar siswa menyadari proses pengerjaan secara benar dan menyadari proses yang dilakukannya. Sejalan dengan prinsip belajar pemberian umpan balik yang di kemukakan (Winataputra, 2004) yaitu siswa perlu dengan segera mengetahui apakah yang ia lakukan di dalam proses pembelajaran atau yang ia peroleh dari proses pembelajaran tersebut sudah benar atau belum. Bila ternyata masih salah, pada bagian mana ia masih salah dan mengapa salah serta bagaimana seharusnya ia melakukan kegiatan belajar tersebut. (Winataputra, 2004) memberikan cara bagaimana memberikan umpan balik di antaranya: 1) guru mengatakan bahwa pekerjaan siswa salah, 2) guru mengatakan bahwa pekerjaan siswa masih salah sambil ditunjukkan pada bagian mana masih salah, serta 3) guru menunjukkan kepada siswa pada bagian mana siswa masih salah, kemudian dijelaskan mengapa masih salah dan diminta kepada siswa tersebut untuk memperbaiki bagian yang masih salah itu.

Menurut (Winataputra, 2004) cara ketiga merupakan cara yang lebih baik, karena cara ketiga guru bukan hanya menyalahkan, akan tetapi menjelaskan pula kepada siswa mengapa pada 
bagian itu siswa masih salah. Dengan cara tersebut siswa akan lebih memahami alasan ia melakukan kesalahan, kemudian mendiskusikannya dengan guru sambil dicari sendiri caracara yang lebih tepat. Dengan cara seperti itu kadar aktivitas belajar siswa lebih tinggi. Siswa tidak terlalu banyak bergantung pada guru, karena siswa lebih banyak mencari dan menemukan. Menurut (Winataputra, 2004) makin berpusat perhatian siswa pada pelajaran, proses belajar makin baik, dan hasilnya akan makin baik pula.

Sejalan dengan teori Pavlov (2001) mengemukakan konsep pembiasaan bahwa agar siswa belajar dengan baik maka harus dibiasakan mengerjakan soal dan pekerjaan rumah, kemudian guru memeriksanya, menjelaskannya, memberi nilai terhadap hasil pekerjaannya. Thorndike (2001) pada hukum latihannya mengemukakan jika suatu pengulangan sering terjadi, makin banyak kegiatan yang dilakukan siswa maka hubungan yang terjadi akan bersifat otomatis. Skinner (2001) menyatakan bahwa ganjaran atau penguatan mempunyai peranan yang amat penting dalam proses belajar. Skinner (2001) menyatakan bahwa penguatan yang diberikan pada anak memperkuat tindakan mereka, sehingga anak semakin sering melakukannya. Menurut aliran latihan mental mengemukakan bahwa struktur otak manusia terdiri dari gumpalan-gumpalan otot. Agar otak itu kuat maka harus dilatih dengan beban, makin banyak latihan dan beban yang makin berat maka otot (otak) itu makin kuat pula. Oleh karena itu, jika siswa ingin pandai maka siswa harus dilatih otaknya dengan cara banyak berlatih memahami dan mengerjakan soal-soal yang benar, makin sukar materi itu makin pandai pula siswa tersebut.

Berdasarkan teori yang dikemukakan di atas, maka tepat jika penguatan terhadap kegiatan latihan siswa perlu diberikan. Penguatan akan berbekas pada diri siswa. Mereka yang mendapat hadiah atau pujian setelah berhasil menyelesaikan tugas akan termotivasi untuk rajin belajar dan mempertahankan prestasi yang diraihnya. Menurut (Winataputra, 2004) bila seorang yang sedang belajar menyadari bahwa tujuan yang hendak dicapai berguna atau bermanfaat baginya, maka motivasi belajarnya akan muncul dengan kuat. Karena penguatan berbekas pada diri siswa, maka penguatan yang diberikan harus diarahkan pada respon yang benar. Sebaliknya jika respon siswa salah, harus diberi penguatan negatif agar respon tersebut tidak diulang lagi dan berubah jadi respon yang sifatnya positif. Penguatan negatif ini bisa berupa teguran, peringatan, atau sanksi (hukuman edukatif).

\section{Simpulan dan Saran}

Berdasarkan analisis dan pengujian hipotesis dari hasil penelitian, maka didapat kesimpulan: 1) kemampuan pemahaman matematika siswa yang selalu diberi catatan perbaikan lebih baik daripada siswa yang jarang dan tidak diberi catatan perbaikan; 2) kemampuan pemahaman matematika siswa berkemampuan tinggi yang selalu diberi catatan perbaikan lebih baik daripada siswa berkemampuan tinggi yang jarang dan tidak diberi catatan perbaikan; 3) kemampuan pemahaman matematika siswa berkemampuan sedang yang selalu diberi catatan perbaikan lebih baik daripada siswa berkemampuan sedang yang jarang dan tidak diberi catatan perbaikan; 4) kemampuan pemahaman matematika siswa berkemampuan rendah yang selalu dan jarang diberi catatan perbaikan lebih baik daripada siswa berkemampuan rendah yang tidak diberi catatan perbaikan; 5) kemampuan pemahaman matematika siswa berkemampuan tinggi yang selalu diberi catatan perbaikan lebih baik daripada siswa berkemampuan sedang dan rendah yang selalu diberi catatan perbaikan; 6) kemampuan pemahaman matematika siswa berkemampuan tinggi dan sedang yang jarang diberi catatan perbaikan lebih baik daripada siswa berkemampuan rendah yang jarang diberi catatan perbaikan; serta 7) kemampuan pemahaman matematika siswa berkemampuan tinggi yang tidak diberi catatan perbaikan tidak lebih baik daripada siswa berkemampuan sedang dan rendah yang tidak diberi catatan perbaikan. 
Berdasarkan hasil penelitian dan simpulan, penulis memberikan saran khususnya kepada pendidik yaitu: 1) membantu mengatasi kesulitan yang dialami setiap siswa agar kemampuan pemahaman matematika siswa dapat meningkat; 2) mampu menciptakan self-efficacy pada diri siswa, yakni rasa bahwa ia memiliki kemampuan untuk melaksanakan tugas sekolah; 3) memberikan latihan untuk membiasakan siswa melatih kemampuan dan kecepatan dalam belajarnya; 4) memberikan interpretasi mengenai hasil pekerjaan siswa, memberikan penguatan jika pemahaman benar, sebaliknya luruskan pemahamannya yang menyimpang; 5) memberikan kesempatan yang setiap siswa untuk melakukan suatu kegiatan belajar dan latihan; 6) memahami kesulitan pemahaman matematika yang dialami siswa khususnya pada setiap latihan; karena kesulitan yang dialami setiap siswa berbeda-beda; serta 7) memberikan catatan perbaikan merupakan salah satu solusi yang terbukti dapat membantu guru dalam mengatasi kesulitan-kesulitan siswa sehingga kemampuan pemahaman siswa dapat meningkat.

\section{Daftar Pustaka}

Bahri Djamarah, S. (2002). Psikologi Belajar. Jakarta: Rineka Cipta.

Dimyati dan Mudjiono. (2006). Belajar dan Pembelajaran. Jakarta: Rineka Cipta.

Gunawan, Rony. (2001). Kamus Lengkap Bahasa Indonesia. Surabaya: Terbit Terang.

Hilaliyah, Tatu. (2004). Penilaian Hasil Belajar. Serang: Untirta.

Mulyasa, E. (2004). Kurikulum Berbasis Kompetensi. Bandung: Rosda karya.

Nasution. S. (1986). Didaktik Asas-Asas Mengajar. Bandung: Jemars.

Sugiyono. (2007). Statistika untuk Penelitian. Bandung: Alfabeta.

Sumarmo, Utari. (2003). Pembelajaran Matematika untuk Mendukung Pelaksanaan Kurikulum Berbasis Kompetensi. Makalah FPMIPA UPI. Bandung: Tidak Diterbitkan.

TIM MKPBM. (2003). Strategi Pembelajaran Matematika Kontemporer. Jakarta: Jica.

Tim Penyusun Kamus Pusat Bahasa. (2005). Kamus Besar Bahasa Indonesia. Jakarta: Balai Pustaka.

Wilis Dahar, Ratna. (1996). Teori-teori Belajar. Bandung: Erlangga. 